\title{
Correction to: Effects of residual stresses and compressive mean stresses on the fatigue strength of longitudinal fillet-welded gussets
}

Jonas Hensel $^{1} \cdot$ Thomas Nitschke-Pagel $^{1} \cdot$ Klaus Dilger $^{1}$

Published online: 17 May 2021

(C) International Institute of Welding 2021

\section{Correction to: Welding in the World https://doi.org/10.1007/s40194-015-0284-6}

The article Effects of residual stresses and compressive mean stresses on the fatigue strength of longitudinal fillet-welded gussets, written by Jonas Hensel, Thomas Nitschke-Pagel, and Klaus Dilger, was originally published electronically on the publisher's Internet portal on 12 January 2016 without open access. With the author(s)' decision to opt for Open Choice, the copyright of the article changed on 7 May 2021 to $($ ) The Authors 2021, and the article is forthwith distributed under a Creative Commons Attribution Attribution 4. 0 International License, which permits use, sharing, adaptation, distribution, and reproduction in any medium or format, as long as you give appropriate credit to the original author(s) and the source, provide a link to the Creative Commons License, and indicate if changes were made. The images or other third party materials in this article are included in the article's Creative Commons License, unless indicated otherwise in a credit line to the material. If material is not included in the article's Creative Commons License and your intended use is not permitted by statutory regulation or exceeds the permitted use, you will need to obtain permission directly from the copyright holder. To view a copy of this license, visit http://creativecommons.org/licenses/by/4.0.

Publisher's note Springer Nature remains neutral with regard to jurisdictional claims in published maps and institutional affiliations.

The online version of the original article can be found at https://doi.org/ 10.1007/s40194-015-0284-6

Jonas Hensel

j.hensel@tu-braunschweig.de

Institute of Joining and Welding, TU Braunschweig,

Braunschweig, Germany 